\title{
The 2011-12 pilot European Sentinel Registry of Transcatheter Aortic Valve Implantation: in-hospital results in 4,571 patients
}

\author{
Carlo Di Mario ${ }^{*}$, MD, PhD; Helene Eltchaninoff ${ }^{2}$, MD; Neil Moat ${ }^{1}$, MS, FRCS; Javier Goicolea ${ }^{3}$, MD; \\ Gian Paolo Ussia ${ }^{4}$, MD; Petr Kala ${ }^{5}$, MD, PhD; Peter Wenaweser ${ }^{6}, \mathrm{MD}$; Marian Zembala ${ }^{7}, \mathrm{MD}, \mathrm{PhD}$; \\ Georg Nickenig ${ }^{8}, \mathrm{MD}, \mathrm{PhD}$; Eduardo Alegria Barreroํ, MD; Thomas Snow ${ }^{1}, \mathrm{MD}$; Bernard Iung ${ }^{9}, \mathrm{MD}$; \\ Pepe Zamorano ${ }^{10}$, MD; Gerhard Schuler ${ }^{11}$, MD; Roberto Corti ${ }^{12}$, MD; Ottavio Alfieri ${ }^{13}$, MD; \\ Bernard Prendergast ${ }^{14}$, DM; Peter Ludman ${ }^{15}$, MD; Stephan Windecker ${ }^{6}$, MD; Manel Sabate ${ }^{16}, \mathrm{MD}, \mathrm{PhD}$; \\ Martine Gilard ${ }^{17}$, MD; Adam Witowski ${ }^{18}$, MD, PhD; Haim Danenberg ${ }^{19}$, MD; Erwin Schroeder ${ }^{20}$, MD; \\ Francesco Romeo ${ }^{21}$, MD; Carlos Macaya ${ }^{22}, \mathrm{MD}, \mathrm{PhD}$; Genevieve Derumeaux ${ }^{23}, \mathrm{MD}, \mathrm{PhD}$; Aldo Maggioni ${ }^{24}$, MD; \\ Luigi Tavazzi ${ }^{25}$, MD, PhD: on behalf of the Transcatheter Valve Treatment Sentinel Registry (TCVT) \\ Investigators of the EURObservational Research Programme (EORP) of the European Society of Cardiology
}

1. Royal Brompton Hospital, London, United Kingdom; 2. University Hospital, Rouen, France; 3. Hospital Universita Puerta de Hierro, Madrid, Spain; 4. Ferrarotto Hospital, University of Catania, Catania, Italy; 5. Masaryk University, University Hospital Brno, Brno, Czech Republic; 6. Bern University Hospital, Bern, Switzerland; 7. Silesian Centre for Heart Disease, Zabrze, Poland; 8. University Hospital, Bonn, Germany; 9. Bichat Hospital, Paris, France; 10. Hospital Universitario Ramon y Cajall, Madrid, Spain; 11. Herzzentrum Leipzig Abt. Kardiologie und Angiologie, Leipzig, Germany; 12. Univeristy Hospital, Zurich, Switzerland; 13. Ospedale San Raffaele Milan, Italy, 14. John Radcliffe Hospital, Oxford, United Kingdom; 15. Queen Elizabeth Hospital, Birmingham, United Kingdom; 16. Thorax Institute, Hospital Clinic, Barcelona, Spain; 17. Centre Hospitalier Universitaire (CHU) Brest, Brest, France; 18. Institute of Cardiology, Warsaw, Poland; 19. Hadassah-Hebrew University Medical Center, Jerusalem, Israel; 20. UCL de Mont-Godinne, Yvoir, Belgium; 21. University of Rome Tor Vergata, Rome, Italy; 22. Clinico 'San Carlos' University Hospital, Madrid, Spain; 23. University of Lyon, Lyon, France; 24. ANMCO Research Center, Florence, Italy; 25. GVM Hospitals of Care and Research, Ettore Sansavini Health Science Foundation, Cotignola, Italy

This paper also includes accompanying supplementary data published at the following website: www.eurointervention.org

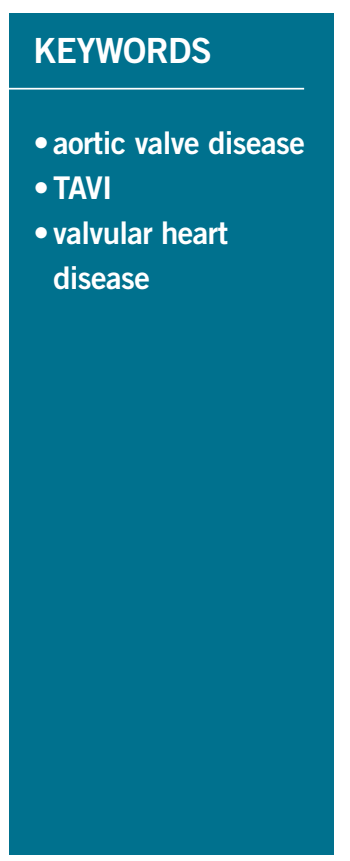

\begin{abstract}
Aims: The aim of this prospective multinational registry is to assess and identify predictors of in-hospital outcome and complications of contemporary TAVI practice.

Methods and results: The Transcatheter Valve Treatment Sentinel Pilot Registry is a prospective independent consecutive collection of individual patient data entered into a web-based case record form (CRF) or transferred from compatible national registries. A total of 4,571 patients underwent TAVI between January 2011 and May 2012 in 137 centres of 10 European countries. Average age was $81.4 \pm 7.1$ years with equal representation of the two sexes. Logistic EuroSCORE (20.2 \pm 13.3 ), access site (femoral approach: 74.2\%), type of anaesthesia and duration of hospital stay ( $9.3 \pm 8.1$ days) showed wide variations among the participating countries. In-hospital mortality (7.4\%), stroke (1.8\%), myocardial infarction ( $0.9 \%)$, major vascular complications $(3.1 \%)$ were similar in the SAPIEN XT and CoreValve $(\mathrm{p}=0.15)$. Mortality was lower in transfemoral (5.9\%) than in transapical (12.8\%) and other access routes $(9.7 \%$; $<<0.01)$. Advanced age, high logistic EuroSCORE, pre-procedural $\geq$ grade 2 mitral regurgitation and deployment failure predicted higher mortality at multivariate analysis.
\end{abstract}

Conclusions: Increased operator experience and the refinement of valve types and delivery catheters may explain the lower rate of mortality, stroke and vascular complications than in historical studies and registries.

\footnotetext{
*Corresponding author: NIHR Cardiovascular Biomedical Research Unit, Royal Brompton Hospital, Sydney Street, SW3 6NP London, United Kingdom. E-mail: c.dimario@rbht.nhs.uk
} 


\section{Introduction}

Elderly patients with severe symptomatic degenerative aortic valve stenosis are often either at high risk or not suitable candidates for surgery and have a very poor prognosis when left on medical treatment ${ }^{1}$. Europe has played a major role in the development of transcatheter valve treatment, with the first balloon valvuloplasty in $1986^{2}$ and first clinical aortic valve implant in 2002 by Alain Cribier in France ${ }^{3}$. The Placement of Aortic Transcatheter Valves (PARTNER) randomised trial confirmed superiority over medical treatment or equivalency to AVR in patients deemed inoperable ${ }^{4}$ or at high surgical risk ${ }^{5}$. Large registries can be divided into industry sponsored studies limited to specific valve types ${ }^{6,7}$ and national registries reporting country specific results, often starting from the first years of TAVI implantation $^{8-10}$, when operator experience and the size/design of the valves and/or delivery systems used were very different to today. Variations in national health policy and practice, device performance and definitions may account for otherwise inexplicable differences in outcome and complications, such as the rate of permanent pacemaker (PPM) implantation ranging from less than $10 \%$ in Italy ${ }^{11}$ to almost $40 \%$ in Germany ${ }^{4}$. The Sentinel Registry of Transcatheter Valve Treatment is part of the ESC EURObservational Study Programme and reports results of 4,571 patients from 10 pilot countries. These are presented focusing on clinical indications, patient characteristics, procedural approach, in-hospital outcome and complications.

\section{Methods}

\section{PARTICIPATING CENTRES AND STUDY CONDUCTION}

A total of 137 centres throughout 10 European countries contributed to this registry (Online Appendix). Five countries (Czech Republic nine centres, 141 patients, 3.08\%; France - 33 centres, 2,279 patients, 49.86\%; Spain - 26 centres, 689 patients, 15.07\%; Switzerland 12 centres, 129 patients, $2.82 \%$ and the United Kingdom - 25 centres, 886 patients, $19.38 \%$ ) electronically transferred their entire 2011 national database after data monitoring and cleaning. Two countries (Italy, 254 patients, 5.56\% and Poland, 157 patients, 3.43\%) provided consecutive data from 24 active centres between January 2011 or the time of EC approval and May 2012 via a dedicated web-based CRF hosted and managed at Heart House. This generated queries to clean the database and validate entries. Consistency of variable definitions was controlled by the Executive Committee with a threshold for participation set at $90 \%$ of a core group of 112 variables. Whenever possible, and consistent with the practice of existing databases, the Valve Academic Research Consortium (VARC) definitions were applied $^{10}$. Appropriate changes were performed in some of the national databases to ensure consistency. Two countries (Belgium, 20 patients, $0.44 \%$ and Israel, 4 patients, $0.09 \%$ ) did not meet the $90 \%$ threshold and were asked at a later stage to participate via direct electronic submission which was limited to six centres. Germany (12 patients, $0.26 \%$ ) participated only in the mitral component of the Valve Registry with the exception of two centres.

The study protocol and database was designed by the TCVT Registry Executive Committee, with members appointed to represent the various medical subspecialties involved in this multidisci- plinary procedure including interventional cardiologists, cardiac surgeons, intensive cardiac care specialists, cardiac imaging specialists selected from the relevant Working Groups and Associations within the European Society of Cardiology $(\mathrm{ESC})^{12}$. This Committee together with the 10 National Coordinators nominated by the President of each of the National Cardiological Societies, acted as the Registry Steering Committee. The EORP Oversight Committee supervised the conduct of the registry. The pilot registry had no direct or indirect sponsorship from the two companies (Edwards Lifesciences and Medtronic) manufacturing the only two commercial devices available in Europe during the study period.

\section{ENROLMENT CRITERIA}

In the participating centres all consecutive patients receiving transcatheter aortic valve implantation using approved (CE-marked) devices were prospectively entered into the registry. For the national registries, patients provided written informed consent to the TAVI procedure including consent for anonymous processing of the data. An individual specific consent approved by the hospital Ethics Committees of the participating centres was signed by patients directly entered into the TCVT database.

\section{STUDY DEVICES}

Two devices were used throughout the study period. The SAPIEN XT (Edwards Lifesciences Inc., Irvine, CA, USA) is a balloon expandable cobalt chromium open-cell stent mounting a trileaflet valve consisting of bovine pericardial tissue. The CoreValve (Medtronic Inc., Minneapolis, MN, USA) is a self-expandable nitinol stent mounting a prosthesis consisting of porcine pericardial tissue, delivered via an 18 Fr delivery catheter.

\section{ENDPOINTS AND DEFINITIONS}

The aim of this first report of the pilot TCVR is the assessment of indications, modalities of perioperative assessment and procedural technique, in-hospital results and complications. Pre-specified comparisons in the statistical plan included country of enrolment, age groups, access site and type of valve.

The definitions entered into the electronic CRF followed the VARC definitions ${ }^{13}$. The participating countries with existing national registries were encouraged to modify their database to follow these criteria. When this was not feasible endpoints were limited to unequivocal events (for instance death or stroke) without distinction of cardiovascular or non-cardiovascular causes and minor/major strokes. When various definitions were entered for an adverse event such as a haemorrhagic complication, a common unequivocal indicator present in all registries was used (for instance blood transfusions were used as a surrogate for bleeding). Individual definitions are reported in the TCVT study protocol (www.escardio.org/guidelinessurveys/eorp/surveys/Pages/tcvt.aspx).

\section{STATISTICAL ANALYSIS}

Univariate analysis was applied to both continuous and categorical variables. Continuous variables were reported as mean $\pm \mathrm{SD}$ or as 
median and Interquartile Range (IQR). Between-group comparisons were made using a non-parametric test (Kruskal-Wallis test). Categorical variables were reported as percentages. Between-group comparisons were made using a chi-square test or a Fisher's exact test if any expected cell count was less than five. Multivariate analysis was used to explore relationship between mortality and baseline covariates for the TAVI population. The baseline covariates were compared between dead and alive patients at discharge (chisquared or Kruskal-Wallis test for categorical or continuous variables respectively), and only the significant variables were included in the model. Multiple logistic regression was done using a multiple imputation procedure to overcome the limitation caused by the presence of missing data. Instead of filling in a single value for each missing value, Rubin's (1987) multiple imputation procedure replaces each missing value with a set of plausible values that represent the uncertainty about the right value to impute. These multiplied imputed data sets are then analysed by using standard procedures for complete data and combining the results from these analyses. This procedure was performed using the programme $\mathrm{R}$ (http://www.R-project.org/.) and the package Hmisc (http:// CRAN.R-project.org/package $=$ Hmisc). ${ }^{14,15}$

\section{Results}

\section{PATIENT CHARACTERISTICS}

A total of 4,571 patients underwent TAVI between January 2011 and June 2012 in 137 centres of 10 European countries. Average age was $81.4 \pm 7.1$ years and body/mass index was $26.6 \pm 4.9 \mathrm{Kg} / \mathrm{m}^{2}$. NYHA Class III or IV was present in $76.9 \%$ of patients. Patient characteristics are reported in Table 1 for the entire population (Table 1, column 1) and divided for patients with $\leq 80$ years or $>80$ years (Table 1 , columns 2 and 3 ). There is a greater incidence of diabetes, COPD, extracardiac arteriopathy (carotid, peripheral), renal dialysis, prior myocardial infarction, previous cardiac surgery or PCI and previous aortic valve replacement (valve-in-valve procedures) in the younger group.

Despite the greater prevalence of comorbidities in patients $<80$ years of age, they had a significantly lower mean logistic EuroSCORE $(17.4 \pm 13.2$ vs. $22.0 \pm 13.1 ; \mathrm{p}<0.01)$. There were large variations in the average logistic EuroSCORE among the participating countries (Figure 1) with countries like Spain and Italy having an average of $16.2 \pm 10.0$ and $17.6 \pm 13.9$ and countries like the UK and the Czech Republic having an average logistic EuroSCORE of $22.6 \pm 13.3$ and $23.2 \pm 15.7(\mathrm{p}<0.01)$.

Table 1. Patient characteristics and age groups.

\begin{tabular}{|c|c|c|c|c|}
\hline $\begin{array}{c}\text { Variable } \\
\text { (nb observations) }\end{array}$ & $\begin{array}{c}\text { Total, n (\%) } \\
4,571\end{array}$ & $\begin{array}{c}<80, \mathrm{n}(\%) \\
1,721(37.5 \%)\end{array}$ & $\begin{array}{c}>80, \mathrm{n}(\%) \\
2,850(62.4)\end{array}$ & $p$-value \\
\hline Male/Female (4,571 patients) & $2,291(50.1) / 2,280(49.9)$ & $(58.6) /(41.4)$ & $(45.0) /(55.0)$ & $<0.01$ \\
\hline Diabetes mellitus ( 4,547 patients) & $1,259(27.7)$ & $618(36.1)$ & $641(22.6)$ & $<0.01$ \\
\hline Hypertension (3,664 patients) & 2,709 (73.9) & $956(73.3)$ & $1,753(74.3)$ & 0.52 \\
\hline Current smoking (4,357 patients) & $185(4.2)$ & $122(7.4)$ & $63(2.3)$ & $<0.01$ \\
\hline Atrial fibrillation (2,773 patients) & $557(20.1)$ & $177(19.7)$ & $380(20.3)$ & 0.65 \\
\hline COPD $(3,844$ patients $)$ & $981(25.5)$ & $438(31.5)$ & $543(22.1)$ & $<0.01$ \\
\hline Dialysis (3,821 patients) & $265(6.9)$ & $142(10.2)$ & $123(5.1)$ & $<0.01$ \\
\hline Previous stroke (4,282 patients) & $206(12.1)$ & $218(12.7)$ & $333(11.7)$ & 0.32 \\
\hline Previous MI (4,549 patients) & 769 (16.9) & $348(20.3)$ & $421(14.8)$ & $<0.01$ \\
\hline Previous cardiac surgery (4,505 patients) & $824(18.0)$ & $469(27.8)$ & $355(12.6)$ & $<0.01$ \\
\hline Previous $\mathrm{PCl}$ (2,289 patients) & $463(20.2)$ & $227(22.1)$ & $236(18.7)$ & 0.04 \\
\hline Previous PM (3,676 patients) & $430(11.7)$ & $114(8.7)$ & $316(13.3)$ & $<0.01$ \\
\hline Extracardiac arteriopathy (2,707 patients) & $671(24.8)$ & $238(27.1)$ & $433(23.7)$ & $<0.05$ \\
\hline Porcelain aorta (465 patients) & $104(22.4)$ & $58(28.4)$ & $46(17.6)$ & $<0.01$ \\
\hline Chest deformity (409 patients) & $12(2.9)$ & $8(4.6)$ & $4(1.7)$ & 0.08 \\
\hline Previous AVR (2,141 patients) & $74(3.4)$ & $40(4.1)$ & $34(2.9)$ & 0.05 \\
\hline LVEF (701 patients) & $40(5.7)$ & $28(9.5)$ & $12(2.9)$ & $<0.01$ \\
\hline $30-50 \%$ & $191(27.2)$ & $74(25.2)$ & $117(28.7)$ & \\
\hline$>50 \%$ & $470(67.0)$ & $192(65.3)$ & $278(68.3)$ & \\
\hline Significant CAD (Stenosis $>50 \%$ ) (3,343 patients) & $669(20.0)$ & $289(21.5)$ & $380(19.0)$ & 0.07 \\
\hline Significant LM (Stenosis>50\%) (3,343 patients) & $215(6.7 \%)$ & $92(7.01 \%)$ & $123(6.5 \%)$ & 0.54 \\
\hline Logistic EuroSCORE (4,394 patients) & $20.2(13.3)$ & $17.4(13.2)$ & $22.0(13.1)$ & $<0.01$ \\
\hline
\end{tabular}



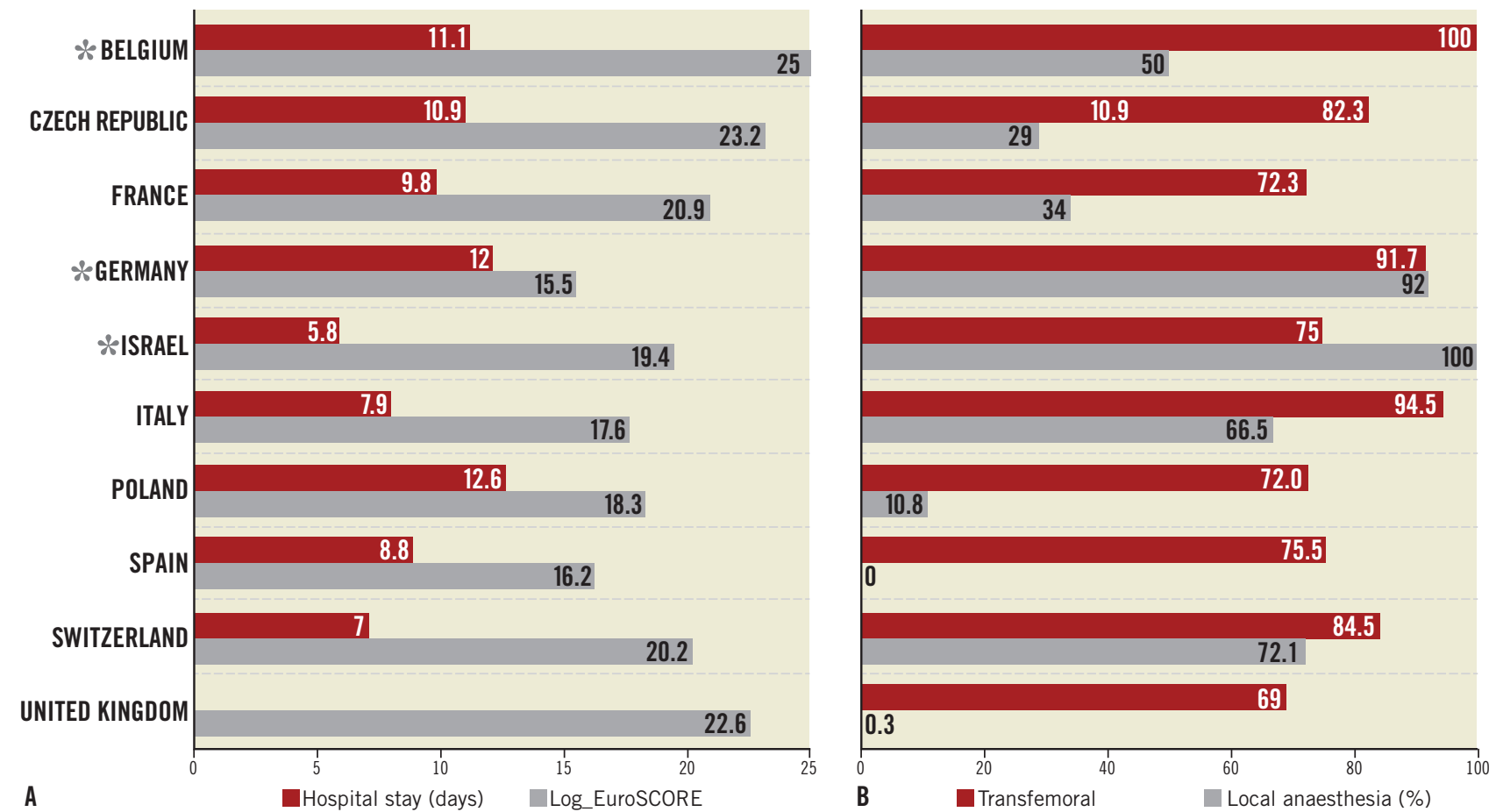

Figure 1. Variations among participating countries. A) Red columns indicate the mean in-hospital stay in days. Note the wide variation from the reported seven days in Switzerland compared to $>12$ days in Poland. Grey columns report the mean logistic EuroSCORE of each participating country. The Czech Republic and the UK reported the highest EuroSCORE (25) whereas Italy, Poland and Spain had $<20$ mean EuroSCORE. B) Red columns represent the percentage of aortic valves implanted via transfemoral access (\%). All cases included from Belgium were performed via transfemoral access, compared to $<70 \%$ in the United Kingdom. Grey columns show the use of local anaesthesia within different countries, ranging from less than $1 \%$ in the UK and Spain to more than half of the patients in Italy and France. Asterisks indicate the three countries (Belgium, Germany and Israel) where the number of patients and centres was insufficient to be representative of national practice in the study period.

\section{PREPROCEDURAL NON-INVASIVE ASSESSMENT}

Transthoracic echocardiography was by far the most frequently used technique for the preprocedural assessment of aortic valve stenosis severity, presence and severity of associated regurgitation, aortic annulus size, left ventricular ejection fraction (LVEF) and concomitant mitral valve disease. Only $10.8 \%$ and $0.3 \%$ of patients are reported to have undergone multislice CT or cardiac MRI, respectively. The baseline mean aortic transvalvular gradient was $49.1 \pm 16.2 \mathrm{mmHg}$ and aortic valve area $0.68 \pm 0.26 \mathrm{~cm}^{2}$ (Figure 2). Preprocedural aortic valve regurgitation was frequent with $16.5 \%$ and $1.7 \%$ reported to have grade 2 and grade 3, respectively. Mitral valve regurgitation graded $\geq 2$ was present in $20.8 \%$ of patients. Preprocedural LVEF was preserved in the majority of patients with a mean of $54.1 \pm 13.8 \%$, with $8.2 \%$ of patients with an ejection fraction $\leq 30 \%$.

\section{PROCEDURE}

The transfemoral route was by far the preferred access site, used in $74.2 \%$ of patients. The transapical route, only applicable with the SAPIEN XT valve was used in $16.4 \%$ of patients $(28.6 \%$ of all SAPIEN XT valves). Other access sites (trans-subclavian, transaxillary, direct aortic, etc.) were used in $9.4 \%$ of cases, more fre- quently using the CoreValve. When patients are divided according to their access route, large differences were observed in clinical characteristics, comorbidities and EuroSCORE (Table 2).

General anaesthesia (GA) was used in $62.9 \%$ of all transfemoral procedures, with wide variations among countries (Figure 1), $\mathrm{p}<0.01$.

SAPIEN XT valves were implanted in 2,604 of the 4,571patients $(57.3 \%)$. Valve selection was skewed towards small diameters with $23 \mathrm{~mm}$ SAPIEN XT and $26 \mathrm{~mm}$ CoreValve used in $44.2 \%$ and $40.8 \%$ of patients and intermediate diameter $26 \mathrm{~mm}$ SAPIEN XT and $29 \mathrm{~mm}$ CoreValve used in $48.7 \%$ and $53.1 \%$ of patients, respectively.

\section{PROCEDURAL RESULTS AND COMPLICATIONS}

The valve was successfully deployed in $96.5 \%$ of patients, without significant differences based on access site (Table 3) or valve type (Table 4). A second valve was required in $2.4 \%$ of cases with surgical conversion occurring in $4.3 \%$.

Overall in-hospital mortality was 7.4\%, similar in SAPIEN XT and CoreValve, without significant differences $(7.9 \%$ vs. $6.7 \%$ : Table 4, $\mathrm{p}=0.15)$. There were however large mortality differences according to approach (transfemoral 5.9\%, transapical $12.8 \%$, trans-subclavian and other approaches 9.7\%, Table 3, $\mathrm{p}<0.01$ ). 
A $\mathrm{cm}$

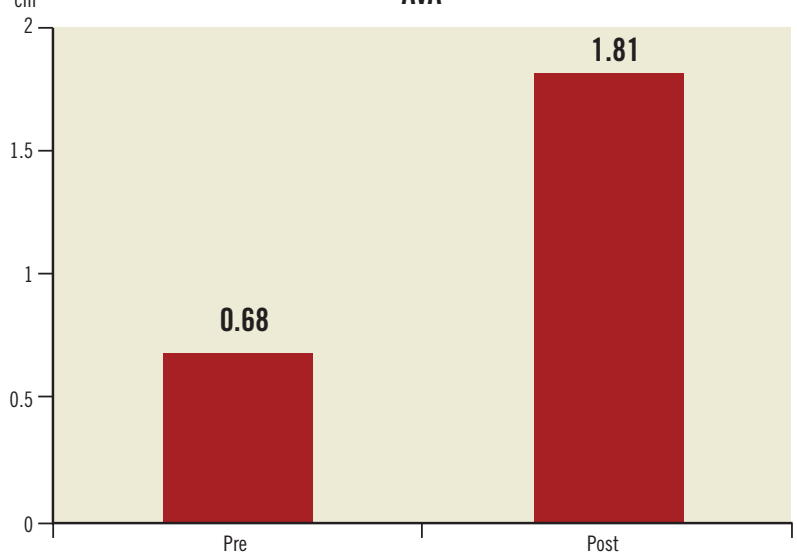

C

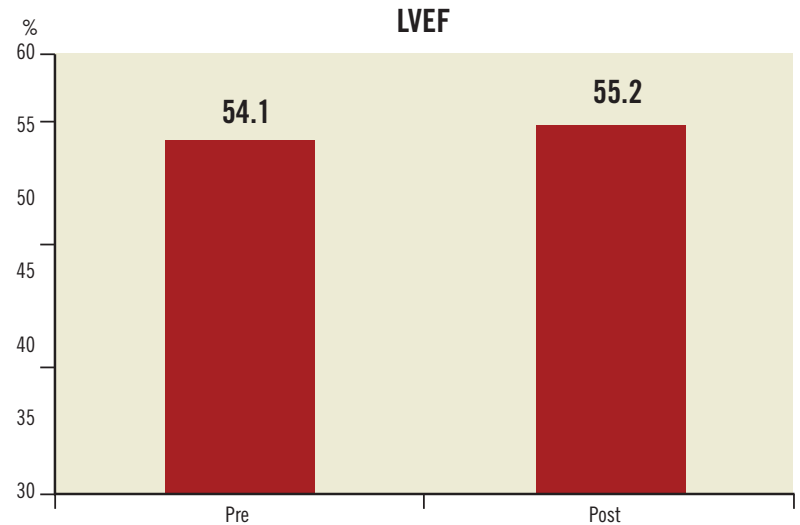

B $\%$

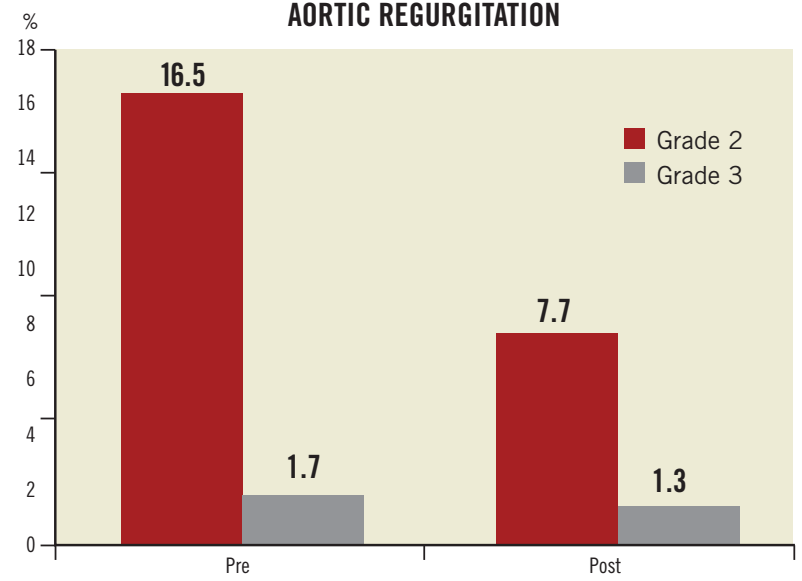

D

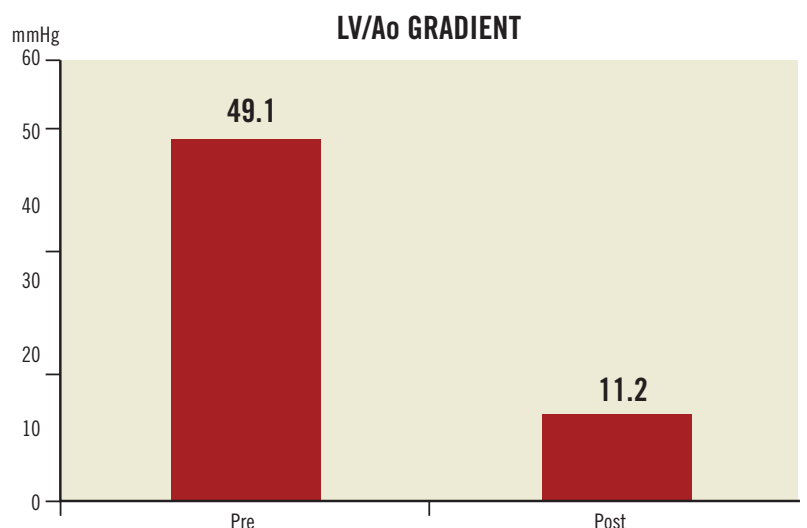

Figure 2. Haemodynamic changes after transcatheter aortic valve implantation. A) Mean aortic valve area (AVA) before and after the procedure. B) Presence of grade 2 and 3 aortic valve regurgitation (\%) before and after the procedure. C) Left ventricular ejection fraction (LVEF) before and after the procedure. D) Left ventricular (LV)/Aortic (Ao) transvalvular mean gradient measured before and after the procedure, with an expected large decrease after valve implantation.

Table 2. Patient and procedural characteristics and access site.

\begin{tabular}{|c|c|c|c|c|}
\hline & $\begin{array}{c}\text { Transfemoral } \\
3,390(74.2 \%)\end{array}$ & $\begin{array}{l}\text { Transapical } \\
749(16.4 \%)\end{array}$ & $\begin{array}{c}\text { Other } \\
432(9.4 \%)\end{array}$ & $p$-value \\
\hline Male/Female & $(46.5) /(53.5)$ & $(62.4) /(37.5)$ & $(57.4) /(42.6)$ & $<0.01$ \\
\hline Diabetes mellitus & $905(26.8)$ & 221 (29.9) & $133(30.9)$ & 0.07 \\
\hline COPD & 719 (25.3) & $131(22.3)$ & $131(31.7)$ & $<0.01$ \\
\hline Dialysis & $176(6.1)$ & $45(7.5)$ & $44(12.6)$ & $<0.01$ \\
\hline Previous MI & $519(15.4)$ & $164(22.1)$ & 86 (19.9) & $<0.01$ \\
\hline Previous cardiac surgery & $543(16.2)$ & $220(30.2)$ & $61(14.2)$ & $<0.01$ \\
\hline Previous $\mathrm{PCl}$ & $331(19.0)$ & $90(24.5)$ & $42(23.3)$ & 0.03 \\
\hline Previous PM & $342(12.3)$ & $53(9.0)$ & $35(11.1)$ & 0.07 \\
\hline Previous AVR (valve-in-valve) & $58(1.7)$ & $9(1.2)$ & $7(1.6)$ & 0.21 \\
\hline$<30 \%$ & $30(5.0)$ & $3(5.6)$ & $7(15.2)$ & 0.07 \\
\hline $30-50 \%$ & $165(27.1)$ & $16(29.6)$ & $12(26.1)$ & \\
\hline$>50 \%$ & 408 (67.9) & $35(64.8)$ & $27(58.7)$ & \\
\hline Significant CAD ( $\geq 1$ vessel) & $477(18.8)$ & $116(23.3)$ & $76(24.8)$ & $<0.01$ \\
\hline Logistic EuroSCORE & $19.6 \pm 12.9$ & $22.2 \pm 14.2$ & $21.6 \pm 13.9$ & $<0.01$ \\
\hline
\end{tabular}


Table 3. Procedural and in-hospital complications and access site.

\begin{tabular}{|c|c|c|c|c|c|}
\hline $\begin{array}{c}\text { Variable } \\
\text { (nb observations) }\end{array}$ & $\begin{array}{c}\text { Total, n (\%) } \\
4,571\end{array}$ & $\begin{array}{c}\text { Transfemoral } \\
3,390(74.2 \%)\end{array}$ & $\begin{array}{c}\text { Transapical } \\
749(16.4 \%)\end{array}$ & $\begin{array}{c}\text { Other } \\
432(9.4 \%)\end{array}$ & $p$-value \\
\hline General anaesthesia ( 4,571 patients) & $2,881(63.0)$ & $2,132(62.9 \%)$ & $749(100 \%)$ & $408(94.4)$ & $<0.01$ \\
\hline Unsuccessful valve delivery (4,441 patients) & $155(3.5)$ & $106(3.2)$ & $36(4.9)$ & $13(3.0)$ & 0.07 \\
\hline Surgical conversion (4,558 patients) & $194(4.26)$ & $159(4.7)$ & $24(3.2)$ & $11(2.6)$ & 0.04 \\
\hline Second valve implanted $(3,760$ patients $)$ & $92(2.4)$ & $72(2.6)$ & $13(2.2)$ & $7(1.7)$ & 0.50 \\
\hline Cardiac tamponade $(3,757$ patients $)$ & $91(2.4)$ & $74(2.7)$ & $4(0.7)$ & $13(3.1)$ & 0.01 \\
\hline Device embolisation ( 3,848 patients) & $17(0.4)$ & $15(0.5)$ & $2(0.3)$ & $0(0)$ & 0.35 \\
\hline Major vascular complications (1,332 patients) & $41(3.1)$ & $29(2.9)$ & $4(2.2)$ & $8(5.1)$ & 0.26 \\
\hline Pacemaker implantation (3,313 patients) & $438(13.2)$ & $375(15.5)$ & $24(4.5)$ & $39(10.7)$ & $<0.01$ \\
\hline Haemodialysis/filtration (3,750 patients) & $62(1.6)$ & $33(1.2)$ & $14(2.4)$ & $15(3.6)$ & $<0.01$ \\
\hline Need transfusion(s) (3,789 patients) & $636(16.8)$ & $419(15.0)$ & $122(20.8)$ & $95(22.9)$ & $<0.01$ \\
\hline Stroke $(3,765$ patients $)$ & $69(1.8)$ & $54(1.9)$ & $9(1.6)$ & $6(1.4)$ & 0.68 \\
\hline In-hospital MI (3,883 patients) & $37(0.9)$ & $25(0.9)$ & $4(0.7)$ & $8(1.9)$ & 0.09 \\
\hline New onset AF (2,858 patients) & $166(5.8)$ & $109(5.1)$ & $38(9.0)$ & $19(6.5)$ & $<0.01$ \\
\hline Hospital stay $>10$ days $(3,633$ patients $)$ & 979 (26.9) & $605(22.0)$ & $250(43.8)$ & $124(39.5)$ & $<0.01$ \\
\hline Death $(4,571$ patients $)$ & $338(7.4)$ & $200(5.9)$ & $96(12.8)$ & $42(9.7)$ & $<0.01$ \\
\hline
\end{tabular}

Table 4. Procedural and in-hospital complications and valve type.

\begin{tabular}{|c|c|c|c|c|}
\hline Variable (nb observations) & $\begin{array}{c}\text { Total, n (\%) } \\
4,571\end{array}$ & $\begin{array}{c}\text { CoreValve } \\
1,943(42.6 \%)\end{array}$ & $\begin{array}{c}\text { SAPIEN XT } \\
2,604(57.4 \%)\end{array}$ & p-value \\
\hline Unsuccessful valve delivery ( 4,418 patients) & $149(3.4)$ & $67(3.6)$ & $82(3.2)$ & 0.56 \\
\hline Surgical conversion (4,534 patients) & $192(4.2)$ & $106(5.5)$ & 86 (3.3) & $<0.01$ \\
\hline Second valve implanted (3,737 patients) & $91(2.4)$ & $60(3.7)$ & $31(1.4)$ & $<0.01$ \\
\hline Cardiac tamponade (3,734 patients) & $91(2.4)$ & $37(2.3)$ & $54(2.5)$ & 0.69 \\
\hline Device embolisation (3,824 patients) & $17(0.4)$ & $10(0.6)$ & $7(0.3)$ & 0.18 \\
\hline Major vascular complications (1,312 patients) & $40(3.1)$ & $20(2.8)$ & $20(3.3)$ & 0.66 \\
\hline Pacemaker implantation (3,290 patients) & $436(13.2)$ & $321(23.4)$ & $115(6.0)$ & $<0.01$ \\
\hline Haemodialysis/filtration (3,727 patients) & $62(1.7)$ & $17(1.1)$ & $45(2.1)$ & 0.01 \\
\hline Need transfusion(s) $(3,766$ patients $)$ & $627(16.6)$ & $268(16.7)$ & $359(16.6)$ & 0.97 \\
\hline Stroke $(3,742$ patients) & $69(1.8)$ & $33(2.1)$ & $36(1.7)$ & 0.40 \\
\hline In-hospital MI (3,860 patients) & $37(0.9)$ & $20(1.2)$ & $17(0.8)$ & 0.17 \\
\hline New onset AF (2,853 patients) & $166(5.8)$ & $74(6.3)$ & $92(5.5)$ & 0.33 \\
\hline Hospital stay $>10$ days (3,627 patients) & 977 (26.9) & $386(25.1)$ & $591(28.3)$ & 0.04 \\
\hline Aortic regurgitation grade 2 (2,522 patients) & $194(7.7)$ & $105(9.9)$ & $89(6.1)$ & $<0.01$ \\
\hline Aortic regurgitation grade 3 (2,522 patients) & $34(1.3)$ & $25(2.3)$ & $9(0.6)$ & \\
\hline Death $(4,547$ patients $)$ & $336(7.4)$ & $131(6.7)$ & 205 (7.9) & 0.15 \\
\hline
\end{tabular}

Bleeding requiring blood transfusion(s) was the most frequent complication with an incidence greater than $20 \%$ for transapical and trans-subclavian approaches, and $15.0 \%$ for transfemoral $(\mathrm{p}<0.01)$. The need for implantation of a PPM was significantly greater for the CoreValve than for the SAPIEN XT valve $(23.4 \%$ vs. $6.0 \%$, $\mathrm{p}<0.01)$. There was a low and similar incidence of in-hospital major vascular complications $(3.1 \%)$, stroke $(1.8 \%)$ and myocardial infarction $(0.9 \%)$.

\section{ECHOCARDIOGRAPHIC CHANGES POST-PROCEDURE}

The aortic valve area increased from $0.68 \pm 0.26 \mathrm{~cm}^{2}$ preprocedure to $1.81 \pm 0.55 \mathrm{~cm}^{2}$ postprocedure, with a concomitant reduction in mean gradient (Figure 2). Aortic valve regurgitation in the pre-discharge control echocardiogram (available in 2,522 patients) showed a reduction in the incidence of grade 2 regurgitation to $7.7 \%$ and of grade 3 regurgitation to $1.3 \%$ following TAVI. Post-procedural LVEF remained stable at $55.2 \pm 12.6 \%$. 


\section{MULTIVARIATE PREDICTORS OF MORTALITY}

Advanced age, high logistic EuroSCORE, pre-procedural $\geq$ grade 2 mitral regurgitation and failure to deploy the valve were associated with a significant increase in mortality (Table 5).

\section{IN-HOSPITAL STAY}

Duration of hospital stay for the TAVI procedure was 9.3 \pm 8.1 days. Great variability was shown in the practice in different countries (Figure 1) with a marked prolongation of hospital stay in patients receiving GA (10.2 \pm 8.7 days vs. $7.9 \pm 6.1$ days, $\mathrm{p}<0.01)$, and/or treated using a transapical or other surgical approaches $(43.8 \%$ and $39.5 \%$ stayed in hospital $>10$ days vs. $22.0 \%$ of patients treated transfemorally, $\mathrm{p}<0.01$ ).

\section{Discussion}

The general purpose of the Sentinel Registries of the ESC EuroObservational Research Study is to independently monitor the application of new technologies in Europe, detect regional differences in indication and technique and assess adherence to guidelines. This registry, also in its pilot phase, appears to have reached its goal as it reports results from the largest TAVI database presented so far and has the unique characteristic of being limited to procedures performed between January 2011 and June 2012 using contemporary valves and/or delivery systems.

The first reassuring message provided by this registry concerns indications. The fear that TAVI was going to be indiscriminately applied to younger and low-risk patients in the absence of supportive studies is dispelled by this large registry of contemporary practice, showing an average age approaching 82 years and a EuroSCORE $>20$. As indicated by the recently presented German Registry (GARY), including both TAVI and surgical AVR procedures, the average age of TAVI patients is much older than surgical AVR cohorts, indicating that TAVI in Europe remains principally reserved for very old patients who are known to have not only higher mortality, but also more prolonged hospitalisation and slower recovery after conventional AVR. Data from a previous ESC registry on valve treatment ${ }^{16}$ showed that these patients were often left to medical therapy, which carries very poor prognosis in symptomatic severe aortic valve stenosis. The routine application of this revolutionary technique is likely to prolong survival and improve the quality of life in these patients ${ }^{17}$. In patients younger than 80 years the presence of comorbidities is more frequent than in older patients. This indicates that a stringent selection process has been followed, restricting TAVI in younger patients to those with significant comorbid conditions that confer a markedly increased surgical risk. Very few patients younger than 70 years undergo TAVI in Europe, and only for "special" indications such as valve-in-valve or for prohibitive comorbidities.

The transfemoral approach clearly represents the preferred route in Europe, but the threshold to move towards other routes and the type of alternative varies, with the transapical approach utilised in more than $25 \%$ of patients in Spain or Poland, and seldom applied in Italy or the Czech Republic. In some countries (UK, Italy), patients with peripheral vascular disease, and a risk profile similar to the traditional candidates for a transapical approach, are considered for a variety of "surgical" alternatives, with the direct exposure of the aorta ${ }^{18}$, subclavian ${ }^{19}$ and axillary artery ${ }^{20}$. These techniques appear more frequently applied with the CoreValve, not suitable for a transapical approach, but they are also becoming more commonly applied with the SAPIEN XT valve.

Transthoracic echocardiography (TTE) appears the prevalent modality to confirm the severity of stenosis, assess the diameter of the valve annulus, confirm resolution of the obstruction and determine the presence and severity of post-procedural paravalvular regurgitation $^{21}$. The anteroposterior annulus diameter measured with TTE was still the main guide for valve sizing. One hypothesis is that the use of this technique may be responsible for a systematic underestimation of valve size. Reliance on TTE may therefore aggravate the main problem of transcatheter valves which is paravalvular $\mathrm{AR}^{22,23}$. MSCT was used in only $13.1 \%$ of patients and currently evidence suggests that perimetric measurements may be more accurate for valve selection. The somewhat surprisingly high proportion of smaller valve sizes seen in this registry might support this concept. In spite of the possibly suboptimal valve-to-annulus diameter ratio, this registry showed an incidence of $\geq 2$ aortic regurgitation somewhat lower than in PARTNER or in other registries, with significantly lower regurgitation using the SAPIEN XT valve.

Direct comparison of mortality in this large contemporary registry with previous trials and registries is limited by the incompleteness of 30-day data, forcing us to limit analysis to in-hospital mortality. Overall, the in-hospital mortality of $7.3 \%$ still qualifies TAVI as a high-risk procedure. Transfemoral procedures had a much lower mortality at $3.9 \%$, which was significantly different in the univariate analysis to the transapical cohort. This may be

Table 5. Predictors of in-hospital mortality at multivariate analysis.

\begin{tabular}{|l|c|c|c|}
\multicolumn{1}{|c|}{ Variable } & Odds ratio & 95\% Cl & p-value \\
\hline Age (8-year interval) & 1.18 & $1.01-1.37$ & 0.0414 \\
\hline EuroSCORE (>Q3 vs. $\leq$ Q1) & 1.74 & $1.24-2.46$ & 0.0002 \\
\hline Pre MR (Grade $\geq 2$ vs. no/grade1) & 1.45 & $1.08-1.93$ & 0.0099 \\
\hline Valve successfully deployed (No vs. Yes) & 7.30 & $5.04-10.57$ & $<0.0001$ \\
\hline MR: mitral regurgitation; Q: quartile & & \\
\hline
\end{tabular}


related to the presence of confounders such as comorbidities contraindicating femoral access and it is important to note that this difference ceased to be significant at multivariate analysis. When the other surgical vascular access approaches are considered, there was a trend, despite the similar patient characteristics, for mortality to be lower than with the transapical approach, with an incidence in between transfemoral and transapical. Only procedural failure has a solid 7.3 odds ratio for in-hospital mortality. EuroSCORE and age were also significantly associated with mortality, but the overall predictive value of those two variables was too low to be of practical help to estimate individual survival. Preprocedural mitral regurgitation $\geq 2$ was the fourth parameter shown at multivariate analysis to correlate with in-hospital survival.

In patients with an average age greater than 81 years, life expectancy is already low and the relative importance of quality of life over survival increases. The percentage of stroke is less than $2 \%$ in both valve groups, a reassuring finding when compared with the much higher figures in the PARTNER Trial ${ }^{24}$ and in line with other published European experiences $^{22}$. Major vascular complications were also less frequent than previously reported, probably reflecting improved operator skills five years after the TAVI programme had been started in most centres, as well as smaller catheter size. It should be noted that it is very likely that the incidence of self-reported and unadjudicated complications in registries is likely to be lower than in controlled clinical trials. The most striking difference reported in the various European national registries concern the need for PPM implantation. The average implantation rate observed is $13.2 \%$ but this complication appears very device specific with the CoreValve requiring a pacemaker in $23.4 \%$ of patients and the SAPIEN XT showing a much lower incidence of $6.0 \%$, not far from percentages reported after surgical AVR. Higher CoreValve implantation enabled by increased operator experience and the new AccuTrak delivery system has been claimed to reduce the need for permanent pacemaker implantation and aortic regurgitation, more frequent with suboptimal low (ventricular) implants. This claim may be correct compared with the historical CoreValve series, but such improvement is still not sufficient to align the need for pacemaker implantation and the severity of aortic regurgitation with the results achieved with the SAPIEN XT valve.

Mortality and other major adverse events including vascular complications and bleeding were similar for the two valve types.

Hospital stay approaches 10 days on average and it is difficult to explain differences. Planning of outpatient preliminary investigations and availability of rehabilitation centres with early transfer in the post-operative period may represent confounding organisational variables. General anaesthesia is still favoured by most operators and is the standard in many centres and countries. It certainly offers the operator and the patient a more relaxed experience during the procedure, with the benefit of continuous transoesophageal echocardiographic guidance, but there is a price to pay in terms of duration of procedure and hospital admission.

Based on our results, the recommendation of using aspirin and clopidogrel post TAVI is adopted in only $30 \%$ of patients. This lack of adherence probably reflects the paucity of data upon which this recommendation is based.
This registry has strengths and weaknesses. The electronic transfer of large national databases has obvious advantages in terms of data quality since it ensures consecutive enrolment in all centres with country-based data monitoring and quality control. Still, the use of different definitions or the fact some parameters were not collected forced us to look for a minimum common denominator, which necessarily requires exclusion of some of the variables or acquisition limited to some of the countries. We candidly report the available data for each variable and adopted a statistical method allowing corrections for missing data in multivariate analysis. The goal of this pilot phase was also to raise awareness of these discrepancies and promote the adoption of uniform definitions across Europe. This registry has accelerated the process of creation of national databases in countries such as Spain, Switzerland and the Czech Republic, with this last country adopting almost entirely the web based database of this study stimulating others to follow (Poland, Italy). The absence of a centralised analysis process and independent adjudication is of greater concern for some more subtle adverse events such as post-procedural aortic regurgitation and stroke. Investigators naturally tend to minimise adverse events and magnify success, which may explain the better outcome observed compared with the PARTNER Trial and previous registries. Still it is highly unlikely that investigators willingly report unchecked or false data in a registry reviewed by national authorities, and it is more likely that only clearly evident complications, possibly the most clinically relevant, are picked up and reported. Finally, this initial report of the pilot phase is limited to in-hospital data, making difficult the comparison with studies focused on 30-day events, a time-point recommended as a primary endpoint in the VARC definitions. The poor completeness observed at 30 days is not only a consequence of the fact that centres were allowed enrolment till May 2012, but also reflects possible difficulties maintaining high rates of follow-up in a voluntary initiative. Other registries and studies have succeeded in exploring predictors of late survival. Even if this registry will be continued as a permanent initiative, its main strength is likely to remain the unbiased independent comparison of indications, technique and complications in different European countries, with a database potentially far larger than any other registry, a goal already achieved in this pilot phase.

\section{Conclusions}

This truly contemporary registry, using the most widely used valve types and delivery catheters, suggests that TAVI in Europe is still reserved to very old patients or patients with severe comorbidities and high surgical risk. The technique is in evolution with transfemoral procedures more often done only under local anaesthesia, and novel approaches (trans-subclavian and direct aortic access) challenging the traditional transapical route for patients who are not suitable for a transfemoral approach. Mortality and other adverse events such as stroke, vascular complications and severe aortic insufficiency appear slightly lower than in previous studies and registries, especially for transfemoral procedures. 


\section{Acknowledgements}

Data collection and statistical analysis coordinated and conducted at the European Heart House by Gerard Gracia, Cecile Laroche and Malika Manini and by the EORP Oversight Committee (Angeles Alonso, Luigi Paolo Badano, Jean Fajadet, Roberto Ferrari, Michel Komajda, Piotr Ponikowski, Luigi Tavazzi, Panos Vardas, David Wood).

From the EURObservational Research Programme of the European Society of Cardiology, Sophia Antipolis, France.

\section{Funding}

European Society of Cardiology.

\section{Conflict of interest statement}

C. Di Mario has been sponsored by Edwards Lifesciences and Medtronic to participate in courses in Nyon and Tolochenaz as part of the mandatory certification process for the implantation of both the SAPIEN and the CoreValve. He also receives speakers' fees, grants for clinical trials and sponsorship for the organisation of congresses and courses from Medtronic UK and Medtronic Vascular Europe. E. Eltchaninoff receives Proctor fees from Edwards Lifesciences. N. Moat receives lecture fees from Medtronic. G.P. Ussia received Proctorship fees from both Medtronic and Edwards Lifesciences. P. Wenaweser receives lecture, Proctor and Consultant fees from Medtronic and Edwards Lifesciences. G. Nickenig receives lecture fees from Medtronic. B. Prendergast received speakers' fees from Edwards Lifesciences. S. Windecker received lecture, Proctor and Consultant fees from Medtronic and Edwards Lifesciences. The other authors have no conflicts of interest to declare.

\section{References}

1. Carabello B, Paulus WG. Aortic stenosis Lancet. 2009; 373:956-66.

2. Cribier A, Savin T, Saoudi N, Rocha P, Berland J, Letac B. Percutaneous transluminal valvuloplasty of acquired aortic stenosis in elderly patients: an alternative to valve replacement? Lancet. 1986;327:63-7.

3. Cribier A, Eltchaninoff H, Bash A, Borenstein N, Tron C, Bauer F, Derumeaux G, Anselme F, Laborde F, Leon MB. Percutaneous transcatheter implantation of an aortic valve prosthesis for calcific aortic stenosis: first human case description. Circulation. 2002;106:3006-8.

4. Makkar RR, Fontana GP, Jilaihawi H, Kapadia S, Pichard AD, Douglas PS, Thourani VH, Babaliaros VC, Webb JG, Herrmann HC, Bavaria JE, Kodali S, Brown DL, Bowers B, Dewey TM, Svensson LG, Tuzcu M, Moses JW, Williams MR, Siegel RJ, Akin JJ, Anderson WN, Pocock S, Smith CR, Leon MB; PARTNER Trial Investigators. Transcatheter aortic-valve replacement for inoperable severe aortic stenosis. N Engl J Med. 2012;366:1696-704.

5. Kodali SK, Williams MR, Smith CR, Svensson LG, Webb JG, Makkar RR, Fontana GP, Dewey TM, Thourani VH, Pichard AD, Fischbein M, Szeto WY, Lim S, Greason KL, Teirstein PS, Malaisrie SC, Douglas PS, Hahn RT, Whisenant B, Zajarias A, Wang D, Akin JJ, Anderson WN, Leon MB; PARTNER Trial Investigators.Two-year outcomes after transcatheter or surgical aortic-valve replacement. $N$ Engl J Med. 2012;366:1686-95.
6. Thomas M, Schymik G, Walther T, Himbert D, Lefèvre T, Treede H, Eggebrecht H, Rubino P, Colombo A, Lange R, Schwarz RR, Wendler O. One-year outcomes of cohort 1 in the Edwards SAPIEN Aortic Bioprosthesis European Outcome (SOURCE) registry: the European registry of transcatheter aortic valve implantation using the Edwards SAPIEN valve. Circulation. 2011;124:425-33.

7. Ussia GP, Barbanti M, Petronio AS, Tarantini G, Ettori F, Colombo A, Violini R, Ramondo A, Santoro G, Klugmann S, Bedogni F, Maisano F, Marzocchi A, Poli A, De Carlo M, Napodano M, Fiorina C, De Marco F, Antoniucci D, de Cillis E, Capodanno D, Tamburino C; CoreValve Italian Registry Investigators.Transcatheter aortic valve implantation: 3-year outcomes of self-expanding CoreValve prosthesis. Eur Heart J. 2012;33:969-76.

8. Zahn R, Gerckens U, Grube E, Linke A, Sievert H, Eggebrecht H, Hambrecht R, Sack S, Hauptmann KE, Richardt G, Figulla HR, Senges J; German Transcatheter Aortic Valve Interventions-Registry Investigators. German Transcatheter Aortic Valve Interventions-Registry Investigators. Transcatheter aortic valve implantation: first results from a multi-centre real-world registry. Eur Heart J. 2011;32:198-204.

9. Eltchaninoff H, Prat A, Gilard M, Leguerrier A, Blanchard D, Fournial G, Iung B, Donzeau-Gouge P, Tribouilloy C, Debrux JL, Pavie A, Gueret P; FRANCE Registry Investigators. Transcatheter aortic valve implantation: early results of the FRANCE (FRench Aortic National CoreValve and Edwards) registry. Eur Heart J. 2011;32:191-7.

10. Moat NE, Ludman P, de Belder MA, Bridgewater B, Cunningham AD, Young CP, Thomas M, Kovac J, Spyt T, MacCarthy PA, Wendler O, Hildick-Smith D, Davies SW, Trivedi U, Blackman DJ, Levy RD, Brecker SJ, Baumbach A, Daniel T, Gray H, Mullen MJ. Long-term outcomes after transcatheter aortic valve implantation in high-risk patients with severe aortic stenosis: the U.K. TAVI (United Kingdom Transcatheter Aortic Valve Implantation) Registry. J Am Coll Cardiol. 2011;58: 2130-8.

11. Fraccaro C, Buja G, Tarantini G, Gasparetto V, Leoni L, Razzolini R, Corrado D, Bonato R, Basso C, Thiene G, Gerosa G, Isabella G, Iliceto S, Napodano M. Incidence, predictors, and outcome of conduction disorders after transcatheter self-expandable aortic valve implantation. Am J Cardiol. 2011;107:747-54.

12. Di Mario C, Alfieri O, Iung B, Serruys PW. Transcatheter valves and interventional cardiology. EuroIntervention. 2011;6:673-7.

13. Leon MB, Piazza N, Nikolsky E, Blackstone EH, Cutlip DE, Kappetein AP, Krucoff MW, Mack M, Mehran R, Miller C, Morel MA, Petersen J, Popma JJ, Takkenberg JJ, Vahanian A, van Es GA, Vranckx P, Webb JG, Windecker S, Serruys PW. Standardized endpoint definitions for transcatheter aortic valve implantation clinical trials: a consensus report from the Valve Academic Research Consortium. Eur Heart J. 2011;32:205-17.

14. R Development Core Team 2011. A language and environment for statistical computing. R Foundation forStatistical Computing, Vienna, Austria. ISBN 3-900051-07-0, URL http://www.R-project.org/. 
15. Frank E Harrell Jr and with contributions from many other users. (2011). Hmisc: Harrell Miscellaneous. R package version 3.9-0. http://CRAN.R-project.org/package=Hmisc.

16. Iung B, Baron G, Butchart EG, Delahaye F, GohlkeBärwolf C, Levang OW, Tornos P, Vanoverschelde JL, Vermeer F, Boersma E, Ravaud P, Vahanian A. A prospective survey of patients with valvular heart disease in Europe: The Euro Heart Survey on Valvular Heart Disease. Eur Heart J. 2003;24:1231-43.

17. Ussia GP, Barbanti M, Cammalleri V, Scarabelli M, Mulè M, Aruta P, Pistritto AM, Immè S, Capodanno D, Sarkar K, Gulino S, Tamburino C. Quality-of-life in elderly patients one year after transcatheter aortic valve implantation for severe aortic stenosis. EuroIntervention. 2011;7:573-9.

18. Alegría-Barrero E, Chan PH, Di Mario C, Moat NE. Direct aortic transcatheter aortic valve implantation: a feasible approach for patients with severe peripheral vascular disease. Cardiovasc Revasc Med. 2012;13:201.e5-7.

19. Petronio AS, De Carlo M, Bedogni F, Maisano F, Ettori F, Klugmann S, Poli A, Marzocchi A, Santoro G, Napodano M, Ussia GP, Giannini C, Brambilla N, Colombo A. 2-Year results of CoreValve implantation through the subclavian access: a propensity-matched comparison with the femoral access. J Am Coll Cardiol. 2012 Jun 7. [Epub ahead of print].

20. Schäfer U, Ho Y, Frerker C, Schewel D, Sanchez-Quintana D, Schofer J, Bijuklic K, Meincke F, Thielsen T, Kreidel F, Kuck KH. Direct percutaneous access technique for transaxillary transcatheter aortic valve implantation. J Am Coll Cadiol Intv. 2012;5:477-86.

21. Zamorano JL, Badano LP, Bruce C, Chan KL, Gonçalves A, Hahn RT, Keane MG, La Canna G, Monaghan MJ, Nihoyannopoulos P, Silvestry FE, Vanoverschelde JL, Gillam LD. EAE/ASE recommendations for the use of echocardiography in new transcatheter interventions for valvular heart disease. $J$ Am Soc Echocardiogr. 2011;24: 937-65.

22. Gilard M, Eltchaninoff H, Iung B, Donzeau-Gouge $\mathrm{P}$, Chevreul K, Fajadet J, Leprince P, Leguerrier A, Lievre M, Prat A, Teiger E, Lefevre T, Himbert D, Tchetche D, Carrié D, Albat B, Cribier A, Rioufol G, Sudre A, Blanchard D, Collet F, Dos Santos P, Meneveau N, Tirouvanziam A, Caussin C, Guyon P, Boschat J, Le Breton H, Collart F, Houel R, Delpine S, Souteyrand G, Favereau X, Ohlmann P, Doisy V, Grollier G, Gommeaux A, Claudel JP, Bourlon F, Bertrand B, Van Belle E, Laskar M; FRANCE 2 Investigators. Registry of transcatheter aortic-valve implantation in high-risk patients. $N$ Engl J Med. 2012;366:1705-15.

23. Staubach S, Franke J, Gerckens U, Schuler G, Zahn R, Eggebrecht H, Hambrecht R, Sack S, Richardt G, Horack M, Senges J, Steinberg DH, Ledwoch J, Fichtlscherer S, Doss M, Wunderlich N, Sievert H; on behalf of the German Transcatheter Aortic Valve Implantation-Registry Investigators. Impact of aortic valve calcification on the outcome of transcatheter aortic valve implantation: Results from the prospective multicenter German TAVI registry. Catheter Cardiovasc Interv. 2012 May 4. [Epub ahead of print].

24. Leon MB, Smith CR, Mack M, Miller DC, Moses JW, Svensson LG, Tuzcu EM, Webb JG, Fontana GP, Makkar RR, Brown DL, BlockPC, Guyton RA, PichardAD, Bavaria JE, Herrmann HC, Douglas PS, Petersen JL, Akin JJ, Anderson WN, Wang D, Pocock S; PARTNER Trial Investigators. Transcatheter aortic-valve implantation for aortic stenosis in patients who cannot undergo surgery. NEngl J Med. 2010;363:1597-607.

\section{Online data supplement}

Appendix. Sentinel Registry of Transcatheter Valve Treatment: participating centres. 


\section{Online data supplement}

\section{Appendix. Sentinel Registry of Transcatheter Valve Treatment: participating centres}

TCVT Executive Committee: Carlo Di Mario, UK (Chairman), European Association of Percutaneous Cardiovascular Interventions (EAPCI); Aortic Valve Registry: Neil Moat, UK, Bernard Iung, France, ESC WG on Valve Disease; Gerhard Schuler, Germany, EAPCI; Pepe Zamorano, Spain, European Association of Echocardiography (EAE). Mitral Valve Registry: Ottavio Alfieri, Italy, ESC WG of Cardiovascular Surgery; Olaf Franzen, Denmark, EAPCI; Susanna Price, UK, ESC WG Acute Cardiac Care, L. Tavazzi (Oversight Committee), A. Maggioni (Board consultant for the EURObservational Research Programme)

\section{National Coordinators:}

BELGIUM E. Schroeder, M. Claeys; CZECH REPUBLIC P. Kala; FRANCE H. Eltchaninoff; GERMANY G. Nickenig; ISRAEL H. Danenberg; ITALY F. Romeo, GP. Ussia; POLAND M. Zembala; SPAIN J. Goicolea; SWITZERLAND R. Corti, P. Wenaweser; UNITED KINGDOM B. Prendergast.

\section{EURObservational Research Programme team:}

M. Manini (Head of Dept); G. Gracia, V. Missiamenou, M. Konte (data monitors); C. Laroche (statistician), C. Taylor (IT specialist), E. Fiorucci, E. Folkesson, M. Glemot, PA. McNeill (assistants)

\section{FUNDING}

The following companies are supporting the EURObservational Research programme: GOLD: Abott Vascular, Bayer Pharma, Bristol Myers Squibb (BMS), Pfizer, Boehringer Ingelheim, Daiichi Sankyo Europe, Menarini international Operations, Novartis Pharma, Sanofi-Aventis, Servier International. SILVER: Amgen. BRONZE: Boston Scientific International, Merck \& Co. (MSD). The contribution of NICOR to the collection and transfer of the 2011 UK TAVI Registry is gratefully acknowledged.

\section{Participating Centres with local PIs:}

BELGIUM Aalst: M. Vanderheyden, Edegem: M. Claeys, Liège: V. Legrand, J. Beckers, J. Boland, Q. Desiron, D. Henroteaux, S. Pourbaix, O. Vanderperren, Yvoir: M. Buche, P. Chenu, A. Guédès, E. Schroeder.

CZECH REPUBLIC Brno: P. Kala, P. Nemec, M. Tretina, Ceske Budejovice: L. Pesl, Hradec Kralove: J. Stasek, J. Bis, Usti n. Labem: P. Cervinka, Olomouc: R. Stipal, Trinec: M. Branny, Praha: V. Kocka, P. Widimsky, M. Zelizko, M. Mates, J. Horak.

FRANCE Angers: J. Debrux, S. Delepine, A. Furber, F. Pinaud, Besançon: S. Chocron, N. Meneveau, F. Schiele, Bois-Bernard: O. Fabre, A. Gommeaux, P. Hochart, M. Pecheux, Brest: E. Bezon, J. Boschat, JN. Choplain, M. Gilard, Bron: R. Dauphin, G. Durand De Gevigney, G. Finet, O. Jegaden, JF. Obadia, G. Rioufol, Caen: G. Grollier, T. Lognone, M. Massetti, R. Sabatier, Caluire-etCuire: JP. Claudel, F. Gabrielle, F. Pelissier, G. Tremeau, Clermont-Ferrand: K. Azarnouch, N. Durel, A. Inorta, JR. Lusson, G. Souteyrand, Créteil: JL. Dubois Rande, M. Kirsch, E. Teiger, Grenoble: B. Bertrand, O. Chavanon, P. Porcu, G. Vanzetto, Le
Chesnay: O. Bical, P. Deleuze, X. Favereau, A. Jegou, Le Plessis Robinson: A. Azmoun, C. Caussin, S. Ghostine, R. Nottin, Lille: F. Juthier, T. Modine, A. Sudre, E. Van Belle, Marseille: JL. Bonnet, F. Collart, T. Cuisset, D. Grisoli, F. Collet, A. Vaillant, J. Vicat, O. Wittenberg, R. Houel, P. Joly, R. Rosario, Massy: B. Chevalier, A. Farge, P. Garot, T. Hovasse, T. Lefevre, MC. Morice, M. Romano, Monaco: F. Bourlon, Montpellier/Nimes/Perpignan: B. Albat, M. Krastevich, F. Leclercq, C. Piot, L. Schmutz, Neuilly-sur-Seine: JC. Dib, B. Gerardin, T. Waldmann, Paris: D. Blanchard, JN. Fabiani, A. Lafont, R. Zegdi, F. Beygui, J. Collet, P. Leprince, A. Pavie, D. Himbert, P. Nataf, Pessac: E. Choukroun, P. Dos Santos, JP. Guibaud, L. Leroux, Rennes: M. Bedossa, D. Boulmier, H. Le Breton, JP. Verhoye, Rouen: JP. Bessou, A. Cribier, H. Eltchaninoff, C. Tron, Saint-Denis: N. Bonnet, F. Digne, P. Guyon, P. Mesnidrey, Saint-Herblain: D. Crochet, R. Gaudin, JC. Roussel, A. Tirouvanziam, Strabourg: M. Kindo, JP. Mazzucotelli, P. Ohlmann, Toulouse: D. Carrie, G. Fournial, B. Marcheix, D. Tchetche, Tours: O. Bar, C. Barbey, D. Blanchard, S. Chassaing, D. Chatel, O. Le Page, A. Tauran, Vandoeuvre les Nancy: M. Angioi, JP. Carteaux, F. Moulin, JP. Villemot, Villeurbanne: D. Champagnac, V. Doisy, Y. Lienhart, R. Roriz. GERMANY Bad Krozingen: M. Bockstatt, HJ. Buettner, T. Comberg, R. Hoewisch-Pengel, E. Maurer, B. Steiger, Bonn: K. Brunsmann, C. Hammerstingl, P. Lang, M. Lennarz, G. Nickenig, R. Schueler, JM. Sinning, C. Zimmermann, Frankfurt: M. Bürgstein, S. De Bruijn, R. Eckhardt, S. Esfajani, M. Kroth, H. Sievert, M. Sirotina, N. Staiger, R. Talea, Hamburg: S. Baldus, K. Heitmann, B. Kolodzick, Lubeck: P. Radke, H. Schunkert, Münster: H. Baumgartner, A. Hellige, G. Kaleschke, G. Kerckhoff, München: M. Block, D. Brill, A. Erbsloeh, M. Fueller, Neuss: H. Degen, M. Haude, A. Kezic, L. Schürmann, Wuppertal: G. Haltern, M. Seyfarth, J. Szymanski, K. Tiroch. ISRAEL Jerusalem: H. Danenberg, S. Loncar, G. Perlman. ITALY Ospedale Ferrarotto Catania, C. Tamburino; Villa Maria Cecilia, Cotignola-Ravenna, A. Cremonesi; C. Grattoni, Lecce Hospital, Lecce, A. Liso; F. Castriota, Ospedale Arnas Civico, Palermo, A. Stabile; Ospedale Cisanello, Azienda Ospedaliera Universitaria, Pisa, A. Petronio; Policlinico Tor Vergata, Roma, F. Romeo; Istituto Humanitas, Milano, P. Presbitero; Policlinico Umberto I, Roma, G. Sardella.

POLAND Bialystok: S. Dobrzycki, M. Frank, T. Hirnle, P. Kralisz, A. Lukaszewicz, B. Sobkowicz, Bydgoszcz: L. Anisimowicz, J. Kubica, G. Lau, W. Ogorzeja, W. Pawliszak, M. Radomski, A. Sukiennik, I. Swiatkiewicz, M. Woznicki, Gdansk: D. Ciecwierz, D. Jagielak, R. Lango, G. Laskawski, J. Rogowski, R. Targonski, A. Wojtowicz, Katowice: M. Lelek, A. Ochala, R. Parma, G. Smolka, P. Weglarz, W. Wojakowski, Krakow: D. Dudek, B. Kapelak, P. Kleczynski, J. Konstanty-Kalandyk, J. Sadowski, R. Sobczynski, D. Sorysz, J. Trebacz, K. Zmudka, Poznan: M. Grygier, M. Jemielity, M. Lesiak, Warszawa: EK. Biernacka, Z. Chmielak, M. Dabrowski, M. Demkow, Z. Juraszynski, K. Kusmierski, J. Pregowski, W. Ruzyllo, A. Witkowski, Warszawa: R. Chichon, Z. Huczek, J. Kochman, M. Marchel, M. Michalak, G. Opolski, P. Scislo, R. Wilimski, 
K. Byczkowska, RJ. Gil, T. Kulawik, A. Pawlak, K. Suwalski, Wroclaw: W. Banasiak, P. Kubler, K. Reczuch, Zabrze: P. Chodor, Z. Kalarus, M. Krason, A. Lekston, T. Podolecki, R. Przybylski, W. Streb, P. Trzeciak, K. Wilczek, M. Zembala, J. Zembala-John. SPAIN La Coruña: JJ. Cuenca Castillo, J. Salgado Fernandez, N. Vazquez Gonzalez, Alicante: P. Llamas, V. Mainar, Asturias: R. Del Valle, C. Moris De La Tassa, Badajoz: F. Gonzalez De Diego, J. Gonzalez Rodriguez, JR. Lopez Minguez, A. Merchan, Barcelona: A. Cequier Fillat, R. Romaguera, M. Castella, J. Mulet, M. Sabate Tenas, M. Jimenez, JM. Padro, A. Serra, F. Mauri, C. Oliete, X. Ruyra, B. Garcia, A. Igual, V. Serra Garcia, Bilbao: J. Alcibar, JI. Aramendi, JM. Aguirre Salcedo, L. Andraka, AA. Morist, J. Zuazo Meabe, Granada: E. Molina Lerma, Guipuzcoa: I. Gallo, J. Goiti, M. Larman, A. Saenz, Huelva: J. Diaz Fernandez, A. Gomez Menchero, Leon: M. Alvarez García, M. Castano, F. Fernandez Vazquez, J. Gualis Cardona, Madrid: F. Navarro Del Amo, A. Albarran Gonzalez-Trevilla, JM. Cortina, J. Tascon, J. Cobiella, E. Garcia, R. Hernandez Antolin, E. Rodriguez Hernandez, L. Martinez Elbal, F. Fernandez-Aviles Diaz, A. Gonzalez Pinto, J. Rodriguez Roda, JL. Zunzunegui, O. Al-Razzo, JM. Mesa, R. Moreno, P. Salinas, J. Goicolea Ruigomez, JF. Oteo Dominguez, J. Ugarte, A. Epeldegui, I. Garcia Andrade, J. Pey Yllera, Malaga: OG. Albarova, JH. Alonso Briales, JM. Hernandez Garcia, AJ. Munoz Garcia, C. Urbano Carrillo, Murcia: R. Arcas, E. Pinar, M. Valdes, Salamanca: I. Cruz, J. Martin Moreiras, Santander:
JM. Revuelta, J. Zueco, Santiago de Compostela: AL. Fernandez Gonzalez, D. Lopez, R. Trillo Nouche, Sevilla: JM. Barquero Aroca, RR. Salmeron, JM. Borrego, JM. Cubero Gomez, A. Sanchez, Toledo: A. Canas, J. Moreu Burgos, Valencia: O. Albarova, A. Berenguer, S. Canovas Lopez, Valencia: J. Anastasio Romero, Vigo: A. Iniguez, V. Jimenez, J. Montoto Lope, G. Pradas.

SWITZERLAND Bern: P. Wenaweser, C. Huber; Basel: R. Jeger, F. Rütter; Geneve: M. Roffi, S. Noble; Lugano: G. Pedrazzini, F. Siclari; Lausanne: D. Locca, E. Ferrari Triemlispital, Zurich: David Tueller, Michele Genoni; Zurich: L. Altwegg, J. Grünenfelder. UNITED KINGDOM Belfast: G. Manoharan, R. Jeugnathan; Birmingham: S. Doshi, P. Ludman, J. Mascaro; Brighton: D. HildickSmith, U. Trevedi; Bristol: A. Baumbach, M. Turner; Blackpool: DH. Roberts, A. Tang; Cambridge: C Densem, S. Tsui; Cardiff: Derriford; Leeds: D. Blackman, M. McLenegham, P. Kaul; Leicester: J. Kovac, T. Spyt; Liverpool: R. Stables, M. Kuduvalli; London: C. Knight; C. Di Mario, N. Moat, S. Price, T. Snow; M. Dalby, M. Amrani; I. Mallik, G. Michail, A. Chuckwemeka; P. McCarthy, O. Wendler; S. Brecker, M. Jahangiri; S. Redwood, M. Thomas, C. Young; M. Mullen, J. Yap; Manchester: F. Ordoubadi; Middlesborough: M. de Belder, A. Goodwin; Morriston: A. Chase, A. Youhana; Newcastle; Nottingham: R. Henderson, I. Mitchell; Oxford: B. Prendergast, R. Sayeed; Plymouth: I. Cox, C. Lloyd; Southampton: A. Calver, N. Curzen, G. Tsang; Stoke-on-Trent: M. Gunning, A. Levive; Wolverhampton: S. Khogali, B. Moninder. 